\title{
JUSTIÇA PENAL AUTORITÁRIA E CONSOLIDAÇÃO DO ESTADO PUNITIVO NO BRASIL
}

\author{
Débora Pastana
}

\begin{abstract}
RESUMO
A transição democrática brasileira, ainda em curso, tem esbarrado na enorme dificuldade em inserir a atuação penal nesse paradigma político. Mais do que isso, os limites ao processo de democratização, demarcados na atuação desse setor estatal, nos remete à idéia de que o campo jurídico ficou imune às mudanças democráticas. Mesmo que o discurso corrente entre os profissionais do Direito afirme a democratização da Justiça Penal, observa-se, na prática, uma forte resistência do campo jurídico em assumir a sua responsabilidade política na consolidação democrática. Este artigo reporta análises e conclusões formuladas a partir de observações sobre a Justiça Penal brasileira e que deram origem à tese intitulada "Justiça Penal no Brasil atual: discurso democrático - prática autoritária”. O objetivo dessa pesquisa foi refletir sobre a política criminal contemporânea, voltada à ampliação da repressão e ao uso contínuo do encarceramento. Tal política, realizada no Brasil logo após a abertura política, ocorrida em 1985, ajustase ao projeto liberal também em curso no país e em praticamente todo o Ocidente capitalista. Como pode ser observado, a Justiça Penal, mesmo durante a execução da pena, opera de forma autoritária e excludente, ao suprimir ao máximo os direitos previstos em lei para os condenados, adotando uma postura altamente repressiva, revelada pelos ínfimos percentuais de benefícios concedidos. No Brasil, as respostas à criminalidade consistem, portanto, em sua grande maioria, em penas severas, traduzidas na ausência do respeito às garantias constitucionais e no recurso amplo ao encarceramento. Nessa linha, nossos governos democráticos contemporâneos freqüentemente adotam uma posição punitiva que visa reafirmar a aptidão do Estado em punir e controlar a criminalidade.
\end{abstract}

PALAVRAS-CHAVE: controle penal; encarceramento; democracia tutelada; Estado punitivo; Sociologia da Violência.

\section{INTRODUÇÃO}

Atualmente tornam-se cada vez mais freqüentes as críticas ao poder Judiciário e, particularmente, à Justiça Penal brasileira. Questões como a impunidade e a insegurança, por exemplo, permeiam o imaginário social, exigindo por parte desse poder uma atuação cada vez mais adequada aos anseios sociais. Essa insatisfação difusa com a Justiça Penal no Brasil coincide com a recente reabertura política e, de certa forma, contrapõese a ela.

O fato é que nossa transição democrática, ainda em curso, tem esbarrado numa enorme dificuldade em inserir a atuação penal nesse paradigma político. Mais do que isso, os limites ao processo de democratização, presentes na atuação desse setor estatal, remete-nos à idéia de que o campo jurídico ficou imune às mudanças democráticas.

Mesmo que o discurso corrente entre os profissionais do Direito afirme a democratização da
Justiça Penal, na prática observa-se uma forte resistência do campo jurídico em assumir a sua responsabilidade política na consolidação democrática. Aqui vale a inquietação de Quartim de Moraes (2001, p. 16): “Se há tantos 'democratas', por que há tão pouca democracia?”. Certamente porque no cotidiano jurídico o significado do termo "democracia" ou foi reduzido ou adequou-se aos interesses liberais.

Aderindo ao projeto de "Estado Mínimo", no que se refere à gestão econômica, o Brasil adotou o que Lamounier e Souza (2006, p. 48) denominaram "democracia tutelada". Segundo os autores, para orquestrar o desmanche estatal sem contestações políticas capazes de reverter o processo, o Estado "testa até o limite o regime democrático, mas não o suprime em termos estritamente legais”. Além disso, todos os problemas resultantes dessa desregulamentação, como a precarização das relações de trabalho, o desemprego e a dificuldade de acesso aos serviços essenciais, que 
levam invariavelmente ao aumento da criminalidade, não são solucionados, e apenas a conseqüência torna-se questão emergencial. Assim, observa-se o endurecimento das medidas repressivas, "justificado pela retórica de 'defesa interna e externa’ da nação”, retórica esta que visa silenciar os críticos.

Sob esse prisma, materializa-se a figura do "Estado punitivo", que, nas palavras de Loïc Wacquant (2001, p. 7), caracteriza-se por diminuir suas prerrogativas na frente econômica e social e por aumentar suas missões em matéria de segurança, "subitamente relegada à mera dimensão criminal”: "Tornar a luta contra a delinqüência urbana um perpétuo espetáculo moral - como querem policiais e políticos ávidos por explorar o problema - permite reafirmar simbolicamente a autoridade do Estado, justamente no momento em que se manifesta sua impotência na frente de batalha econômica e social” (WACQUANT, 2004, p. 1).

Nesse sentido, ficam cada vez mais evidentes as posturas autoritárias que, atreladas ao liberalismo contemporâneo, vêm sendo incorporadas pelo Estado brasileiro e articuladas, também, pela Justiça Penal.

\section{O AUTORITARISMO NACIONAL}

Por certo que no Brasil, assim como na maioria dos países da América Latina, o autoritarismo antecede a recente ascensão do modelo econômico liberal. De fato, nossa arbitrariedade relacionada ao controle social está atrelada a questões mais complexas da nossa história política. Outra constatação que particulariza a realidade nacional é a crise de legitimidade pela qual passa nossa democracia atual.

Gizlene Neder (1996, p. 132) chega a afirmar que em nossa formação socioeconômica desenvolvemos fantasias de controle social absoluto, a partir da cultura jurídico-política da Península Ibérica. Vera Batista (2001), ao comentar tal afirmação, destaca que "nem o fim da escravidão nem a República romperam com o legado da fantasia absolutista do controle social [...]. A atuação da polícia nas favelas cariocas, tanto quanto a chacina de Eldorado dos Carajás, é a prova viva deste legado".

O próprio Wacquant (2001, p. 8), em nota que fez aos brasileiros, no livro As prisões da miséria, chama a atenção para as especificidades do país. Segundo o autor, por um conjunto de razões liga- das à nossa história e à nossa "posição subordinada na estrutura das relações econômicas internacionais (estrutura de dominação que mascara a categoria falsamente ecumênica de 'globalização')", e a despeito do enriquecimento coletivo decorrente das décadas de industrialização, nossa sociedade "continua caracterizada pelas disparidades sociais vertiginosas e pela pobreza de massa que, ao se combinarem, alimentam o crescimento inexorável da violência criminal, transformada em principal flagelo das grandes cidades".

De fato, em nossa história não há registro de radicalismos capazes de implementar reformas profundas em nossa sociedade personalista, corporativista e rigidamente hierarquizada. Durante os períodos ditatoriais, reagimos à supressão de liberdade com certa veemência, mas nunca chegamos a conquistá-la legitimamente. O fim da nossa última ditadura, por exemplo, foi pactuado. Levantes sociais não assustam a elite dominante, porque ela sabe que, ao menos internamente, a governabilidade está a salvo de ataques políticos.

Essa última asserção justifica-se quando consideramos que, desde a independência, experimentamos pouco mais de trinta anos de democracia, e com baixíssima participação popular. Mesmo as recentes manifestações de massa, após a abertura política - dentre elas a marcha pelas “diretas”, em 1984; as manifestações pelo impeachment do Presidente Collor; as várias Comissões Parlamentares de Inquérito que têm se instalado ao longo do tempo e o movimento nacional pela reforma agrária -, não foram suficientes para levar de forma permanente a uma maior participação da sociedade civil na política.

Esses acontecimentos, longe de representarem estopins históricos capazes de dar início ao amadurecimento político nacional, acabaram traduzidos em levantes efêmeros, quase sempre manipulados pela imprensa (ou condenados por ela) e que, quando não são associados ao vandalismo, são rapidamente esquecidos ou desencorajados. O resultado é uma enorme incapacidade da sociedade em se mobilizar autonomamente para fiscalizar o Estado e identificar o mau funcionamento de suas instituições, dentre elas o Judiciário.

Com efeito, para manter intacta a política liberal que se iniciava no país logo após a abertura política, foi necessário deter a participação ativa e consciente dos cidadãos. A atuação dos movimen- 
tos sociais, por exemplo, mudou radicalmente nessas duas últimas décadas, sendo reprimida de forma violenta, e até mesmo condenada pela sociedade civil. Difundiu-se hegemonicamente a comparação desses movimentos a atos compreendidos como vandalismos e incivilidades. Essa idéia, além de retirar a legitimidade dos poucos existentes, inibiu a organização de novos sujeitos políticos. A soma desses fatores evidencia a falta de credibilidade e confiança pelas quais passam as instituições democráticas. O cidadão brasileiro é um projeto inacabado.

Por outro lado, uma sociedade historicamente articulada pelo individualismo e pela exclusão social nem sequer vê sentido em associar democracia com mobilização política e reivindicação. Cada vez mais impregnada pelos valores liberais, presentes no mundo atual, que naturalizam a exclusão (à semelhança do darwinismo social), essa sociedade responsabiliza o próprio excluído pela sua condição.

Seja como for, o retorno ao regime democrático trouxe, ao menos, a esperança de "que os direitos humanos alcançados para a proteção das oposições políticas sob as ditaduras militares pudessem vir a ser estendidos para todos os cidadãos, em especial para aqueles grupos mais destituídos e vulneráveis" (PINHEIRO, 1997). No entanto, ainda que as formas mais arbitrárias e brutais de dominação, usuais contra os dissidentes políticos, tenham sido oficialmente eliminadas, a democracia brasileira não conseguiu, até o momento, garantir efetivamente o respeito aos direitos de cidadania presentes em sua legislação, principalmente quando associados ao controle social.

Mesmo a euforia com a abertura política e com a conseqüente ampliação de direitos não foi capaz de consolidar valores democráticos primordiais, como as garantias individuais e a proteção aos direitos humanos. Enfim, se é certo que durante a transição democrática havia a grande esperança de que o fim da ditadura significasse a consolidação do Estado de Direito (idem), também é correto dizer que as práticas autoritárias não foram afetadas substancialmente pelas mudanças políticas.

Não sem razão, observa-se no Brasil contemporâneo uma democracia cujas instituições, longe de se consolidarem, estão cada vez mais submetidas aos interesses privados. Segundo Milton Lahuerta (2003, p. 217), "se há um traço que marca a experiência brasileira no século XX é a presença simultânea de um intenso processo de modernização e de um baixíssimo compromisso com as instituições democráticas". A esse respeito, Florestan Fernandes (1981, p. 207) já havia observado que nossa burguesia adotara, desde o início de sua formação, uma democracia alternativa, cujos valores existiam apenas no plano formallegal, mas eram socialmente inoperantes.

\section{CARACTERÍSTICAS DO ESTADO PUNI- TIVO NO BRASIL}

Nosso legado de autoritarismo e de pouca resistência facilitou, em grande medida, a adequação ao projeto liberal, no fim dos anos 1980. Como bem observa Wacquant (2001, p. 7): "a penalidade neoliberal ainda é mais sedutora e mais funesta quando aplicada em países ao mesmo tempo atingidos por fortes desigualdades de condições e de oportunidades de vida e desprovidos de tradição democrática e de instituições capazes de amortecer os choques causados pela mutação do trabalho e do indivíduo no limiar do novo século”.

Não surpreende, assim, que a nova República tenha se caracterizado pela versão liberal de "fé irrestrita nas leis de mercado e desconfiança intrínseca na democracia” (GROS, 2003, p. 65). Em outras palavras, nosso projeto neoliberal rejeita o Estado e sua função interventora no campo econômico e social, porém projeta na gestão pública a responsabilidade por controlar, ainda que de forma impositiva, todos os transtornos sociais advindos desse modelo, como, por exemplo, o aumento da criminalidade.

Nesse sentido, nossas políticas sociais passaram a ter como meta não mais a garantia de direitos trabalhistas, buscando a consolidação do mercado formal de trabalho, mas sim o puro assistencialismo dirigido focalmente a grupos de extrema penúria (VIANNA, 1998). Tal política vinha de encontro aos interesses da burguesia nacional, "que rejeitavam qualquer coisa parecida com um Estado de Bem-Estar Social, do qual não se beneficiariam, pois ajudariam a financiá-lo com impostos, mas não fariam uso de seus serviços" (FILGUEIRAS, 2006).

Essa repulsa por políticas sociais legítimas ajusta-se ao ideal de aumento da repressão ao crime. Há quase duas décadas vivemos sob a égide de uma Constituição democrática, no entanto, as relações entre os governos e a sociedade caracterizam-se cada vez mais pela ilegalidade e arbitrari- 
edade. Isso fica particularmente claro quando observamos a Justiça Penal. A atuação do sistema penal demonstra, desde logo, o descaso das autoridades com as garantias formais fixadas na Constituição e nos demais códigos que formam o ordenamento jurídico nacional. De acordo com Eduardo Portella (2000, p. 116-121) “o factóide constitucional de 88 não soube evitar essa ancestralidade perversa”.

Em virtude desse viés altamente controlador, no que se refere aos conflitos sociais, cria-se um circulo vicioso que produz um aumento exponencial da insegurança da população frente à violência e que legitima o aumento da repressão ainda que de forma autoritária. Sem alterar os ritos democráticos, o controle penal expande-se através da edição interminável de leis penais que incriminam novas condutas e do tratamento cada vez mais severo e seletivo destinado ao infrator.

Isso significa dizer que o sistema penal brasileiro caminha, atualmente, menos para a consolidação democrática, e muito mais para a atuação simbólica, traduzida em aumento desproporcional de penas, maior encarceramento, supressão de direitos e garantias processuais, endurecimento da execução penal, entre outras medidas igualmente severas. Tal sistema opera no sentido do "excesso de ordem”, único capaz de tranqüilizar nossa atual sociedade de consumo hedonista e individualista.

Exemplo marcante dessa postura é a Lei n. 8 072/1990, que dispõe sobre os crimes hediondos e os a eles assemelhados, em virtude do mandamento constitucional inserido no artigo $5^{\circ}$, inciso XLIII. Lei portadora de inúmeros dispositivos que atentam frontalmente contra a Constituição Federal e que surge em nosso ordenamento como a consagração da ideologia do endurecimento penal, vale dizer: da punição arbitrária e supressora de inúmeros direitos e garantias constitucionais. Feita às pressas e sob forte pressão política, seu texto atingiu diretamente inúmeros princípios penais constitucionais. No campo da execução penal, por exemplo, excluiu o sistema progressivo no cumprimento da pena privativa de liberdade, restringindo-a apenas ao regime fechado ${ }^{1}$.

${ }^{1}$ Somente em 2006, após 16 anos da promulgação da referida lei, o Supremo Tribunal Federal reconheceu o direito dos condenados por crimes hediondos à progressão de regime no cumprimento da pena de prisão (passando, por
A partir da sua promulgação, abriu-se caminho para um Direito Penal simbólico e ilusório, crente na idéia de que somente com a elaboração de leis severas é que o controle da criminalidade dar-se-ia de forma eficaz. Exemplificando, podemos citar a Lei n. 8 930/1994, que introduziu novas figuras no rol dos crimes hediondos (homicídio qualificado, latrocínio, extorsão, entre outros), e a Lei n. 9 695/1998, que passou a considerar a falsificação e a adulteração de remédios igualmente um crime hediondo. Também podemos citar as medidas de recrudescimento na execução penal, como o regime disciplinar diferenciado (instituído pela Lei n. 10 792/2003), e, recentemente, a inclusão do uso de telefone celular como falta disciplinar grave durante o cumprimento da pena (instituída pela Lei n. 11 466/2007).

Nessa esteira, também é oportuno citar os inúmeros projetos de lei que visam à ampliação do "Estado punitivo" no Brasil. Ao analisar a produção legislativa no âmbito criminal, Laura Frade (2007, p. 91) atesta que "dos 646 projetos de lei apresentados nos últimos quatro anos no Congresso Nacional sobre criminalidade, apenas 20 foram no sentido de relaxar algum tipo penal". Ao contrário, um total de 626 projetos destinavam-se a agravar penas, regimes e restrições. Não sem razão, apenas dois relacionavam-se com a delinqüência de colarinho branco.

Esse conjunto de projetos sobre o endurecimento penal, apelidado por Márcio Thomaz Bastos de "pacotão do pânico", prevê, entre outras medidas, a inclusão de vários crimes na categoria dos hediondos, com o conseqüente aumento de pena e redução dos benefícios penais; o aumento do período máximo de prisão, que atualmente é de 30 anos; o aumento de pena para infratores

exemplo, do regime fechado para o semi-aberto, e desse para o aberto). Em votação dividida, o tribunal declarou inconstitucional o artigo que proibia a concessão do benefício a esse grupo de presos. A partir de então, começou-se a admitir a progressão de regime, nos moldes da legislação brasileira, após o cumprimento de 1/6 de pena. Contudo, em março de 2007, esse reconhecimento foi logo suplantado pela Lei n. 11 464/2007, que tornou mais severa a progressão de regime em tais delitos, estabelecendo parâmetros distintos dos moldes comuns. Nos termos do art. $2^{\circ}$, § $2^{\circ}$, da nova redação da Lei n. 8 072/90, a progressão de regime, no caso de apenado primário, só poderá ocorrer após o cumprimento de $2 / 5$ da pena e, no caso de reincidente, de $3 /$ 5 da reprimenda. 
adultos que cometerem delitos com o auxílio de menores; a redução de prazos prescricionais para determinados delitos e a alteração no tempo máximo de internação de menores infratores - dos três anos atuais para um prazo maior, que poderia chegar a 20 anos. Nessa linha, de todos os projetos em tramitação, o mais evidente, no momento, é, sem dúvida, o projeto de emenda constitucional que trata da redução da idade penal.

Como se observa, ideologia mais do que consolidada, essa postura liberal frente ao delito busca radicalizar o controle penal, intensificando a atuação dos órgãos de controle e restringindo cada vez mais a liberdade e o exercício cívico das classes populares. Como destaca Nilo Batista (2003a): “O empreendimento neoliberal, capaz de destruir parques industriais nacionais inteiros, com conseqüentes taxas alarmantes de desemprego; capaz de 'flexibilizar' direitos trabalhistas, com a inevitável criação de subempregos; capaz de, tomando a insegurança econômica como princípio doutrinário, restringir aposentadoria e auxílios previdenciários [...]; esse empreendimento neoliberal precisa de um poder punitivo onipresente e capilarizado, para o controle penal dos contingentes humanos que ele mesmo marginaliza”.

Certamente, a essa altura não cabe mais a ingenuidade de supor que a legitimidade dessa postura penal não passa pela conjuntura econômica e política que vivenciamos. Ao contrário, em tempos de "Estado mínimo", parece que "a única política pública que verdadeiramente se manteve é a política criminal” (idem). Nesse contexto, o novo credo do campo jurídico é o da equação penal que vê na pena severa a única medida capaz de controlar e, até mesmo, diminuir a criminalidade. Mais do que isso, "a pena já não interessa tanto como inflição de sofrimento ou mesmo fórmula desastrada de solução de conflitos: a pena interessa como recurso epistemológico, como instrumento de compreensão do mundo” (idem).

Em outras palavras, em tempos liberais como o atual, o que caracteriza a atuação penal é a noção de emergência, entendida como um momento excepcional a exigir "uma resposta pronta e imediata, que deve durar enquanto o estado emergencial perdure" (BECK, 2004, p. 95). Aqui não cabe qualquer objetivo educador, reformador ou disciplinador, apenas o isolamento e a exclusão.
Esse abandono do discurso jurídico ressocializador ${ }^{2}$ é, também, uma face perversa da atual política criminal associada aos implementos neoliberais, pois permite, cada vez mais, a consideração da punição como simples "instrumento de encerramento de uma população considerada tanto desviante e perigosa como supérflua, no plano econômico" (WACQUANT, 2001, p. 98). Tal punição representa tão somente um mecanismo útil para "segregar uma categoria indesejável" (ibidem).

Para Nilo Batista (2000, p. 107): "Uma das características dos novos sistemas penais do empreendimento neoliberal consiste numa radical transformação nas finalidades da privação de liberdade, que passam daquilo que Zaffaroni chamou de 'ideologias re' (reinserção social, recuperação laborativa, redisciplinamento etc.) a uma assumida técnica de neutralização do condenado [sic]”.

Assim, imbuída do compromisso de extirpar o crime, nossa Justiça Penal luta contra a impunidade, aniquilando, na maioria das vezes, o criminoso condenado. Agindo dessa forma, acaba contribuindo para o aprofundamento das tensões, uma vez que reproduz as relações de desigualdade e dominação.

Sobre o tema, oportuna é a observação de Francisco Oliveira (2000, p. 59-63), ao defender a existência de uma "exceção permanente", uma espécie de "antidemocracia na América”, que se refugia no simulacro de constitucionalidade e que, em suas palavras, "mal disfarça uma dominação que, outra vez, inverte a fórmula, gramsciana, de $80 \%$ de consenso e $20 \%$ de violência, para as proporções opostas".

Atualmente pode-se dizer, sem receio, que vivemos sob a mais violenta intervenção do Estado na vida dos cidadãos, materializada através de uma dominação simbólica articulada pelo medo e pela "democracia tutelada": "Por não sabermos mais distinguir a violência legítima da ilegítima, somos incapazes de determinar a dívida, quer dizer, o preço do ingresso na vida em comum" (GARAPON, 2001, p. 53).

\footnotetext{
2 Figura criada no contexto iluminista para ilustrar a regeneração do infrator amansado pelo sistema jurídico burguês.
} 
Nesse contexto, essa Justiça total passa a ser simultaneamente bombeiro e incendiária. No mesmo movimento, ela incentiva a desconfiança, desqualifica qualquer solução que não seja a penal e apresenta seu único remédio: mais segregação e restrição de liberdade. Esse modelo tem como conseqüência imediata aumentar o número de detentos em proporções inquietantes, fenômeno também percebido em várias democracias contemporâneas.

"Nas cadeias dos EUA, por exemplo, existem aproximadamente 2,1 milhões de presos enquanto em 1972 havia 33 mil. Outros cinco milhões estão sob supervisão dentro do sistema de Justiça Criminal” (GILL, 2005, p. 64). No Brasil, à semelhança dos Estados Unidos, a política de encarceramento tem aumentado vertiginosamente, tendo ultrapassando, no ano de 2008, a marca dos 440000 presos $^{3}$. O sistema penitenciário brasileiro ocupa, de acordo com dados do Departamento Penitenciário Nacional, um total de 1716 estabelecimentos, com 255057 vagas (homens: 240 954; mulheres: 14 103) e, portanto, com um déficit de quase 185000 vagas (DEPEN, 2008).

Tal aumento, dada a sua característica liberal, é, de fato, uma realidade em muitos países ocidentais. Wacquant (2001, p. 81), ao analisar o inchaço das penitenciárias norte-americanas, comentou que, "se fosse uma cidade, o sistema penitenciário americano seria a quarta metrópole do país”. Esse encarceramento em massa reflete, na realidade, uma estrutura de dominação contemporânea que mascara uma exclusão capitalista ainda mais perversa, o isolamento e a neutralização dos miseráveis em praticamente todo o globo.

De fato, como bem assevera Nils Christie (2002, p. 93), "são as decisões político-culturais que determinam a estatística carcerária e não o nível ou evolução da criminalidade". O maior encarceramento não tem, portanto, relação direta com o aumento das práticas criminosas, mas sim

\footnotetext{
3 Segundo dados do Departamento Penitenciário Nacional (Depen), a população carcerária, que em 1988 era de 88 041 presos, o que representava taxa de encarceramento de 65,2 por 100000 habitantes, atingiram, em junho de 2008, espantosos 440013 presos, elevando a taxa de encarceramento para 316,4 por 100000 habitantes. $\mathrm{O}$ aumento foi da ordem de 485\%, o que representa 351972 presos a mais no sistema.
}

com o aumento dos miseráveis, totalmente excluídos do universo do trabalho.

Essa penalização liberal, denominada por Wacquant (2001, p. 10) de "ditadura sobre os pobres”, procura reprimir com severidade "as desordens suscitadas pela desregulamentação da economia, pela dessocialização do trabalho assalariado e pela pauperização relativa e absoluta de amplos contingentes do proletariado urbano, aumentando os meios, a amplitude e a intensidade da intervenção do aparelho policial e judiciário”. A esse respeito, Bauman (1998, p. 53) adverte que, nesse novo contexto, marcado pela intensificação das relações de consumo, "as classes perigosas são assim redefinidas como classes de criminosos”.

Essa massa excluída do trabalho e, consequentemente, do consumo, fica submetida a um gigantesco sistema penal responsável não mais por disciplinar os desviantes, mas sim por conter o refugo social produzido pelo recente contexto liberal. Ironicamente, Wacquant considera tal fenômeno como "uma espécie de único programa público habitacional do capitalismo tardio" (Wacquant apud BATISTA, 2003a).

Reforçando essa tese, Bauman (1999, p. 128$129)$ assevera que atualmente "os governos detêm pouco mais que o papel de distritos policiais superdimensionados”, varrendo os mendigos, perturbadores e ladrões das ruas, e garantindo, com a firmeza dos muros das prisões, a "confiança dos investidores": "Fazer o melhor policial possível é a melhor coisa (talvez a única) que o Estado possa fazer para atrair o capital nômade a investir no bem-estar dos seus súditos; e assim o caminho mais curto para a prosperidade econômica da nação e, supõe-se, para a sensação de 'bem-estar' dos eleitores, é a da pública exibição de competência policial e destreza do Estado" (ibidem).

Como já salientamos, não é de hoje que o Estado brasileiro adota uma política penal de exceção, contrária às noções de democracia e cidadania, e que coloca a questão social como um caso de polícia. Washington Luís pode ter eternizado a frase que resume essa postura autoritária, mas a política já existia antes dele e continua nos dias atuais, perfeitamente adaptada ao contexto neoliberal. Entre nós, a consolidação do "Estado punitivo" apenas agrava nossos males históricos, 
vale dizer, a "deslegitimação das instituições legais e judiciárias, a escalada da criminalidade violenta e dos abusos policiais, a criminalização dos pobres, o crescimento significativo da defesa das práticas ilegais de repressão, a obstrução generalizada ao princípio da legalidade e a distribuição desigual e não eqüitativa dos direitos do cidadão” (WACQUANT, 2001, p. 12).

Não é de surpreender que os valores expressos na atual lógica liberal delimitam o âmbito de atuação da nossa Justiça Penal por meio de demandas sobre o sistema que devem absurdamente articular dois planos: de um lado, a atividade dá-se num contexto democrático; de outro, sua eficiência é julgada pelo grau de severidade com que responde ao delito. Para piorar, os meios de comunicação de massa reforçam cotidianamente a necessidade da maior intervenção penal. Ao explorarem economicamente o problema da violência criminal acabam por legitimar o recrudescimento penal autoritário, que, em última análise, é também um dos fatores responsáveis por expandir o quadro de exclusão social atual.

Sobre o tema, Vera Batista (2001, p. 4) destaca que as campanhas maciças de pânico social veiculada na imprensa permitiram um avanço sem precedentes na internalização do autoritarismo. Segundo a socióloga, pode-se afirmar, sem medo de errar, "que a ideologia do extermínio é hoje muito mais massiva e introjetada do que nos anos imediatamente posteriores ao fim da ditadura”.

A esse respeito, é emblemático o exemplo da cobertura jornalística sobre o recente assassinato do menino carioca João Hélio. O modo sensacionalista com o qual os meios de comunicação noticiaram o crime acabou por ressuscitar a discussão sobre a redução da idade penal no país. Mesmo a intelectualidade, representada pelo filósofo Renato Janine Ribeiro (2007), passou a clamar por "suplícios medievais" e pena de morte, como punição para os criminosos. Alguns meses depois, a Comissão de Constituição e Justiça do Senado 4

\footnotetext{
4 A Comissão aprovou, no dia 26 de abril de 2007, por 12 votos a 10, a Proposta de Emenda Constitucional (PEC) que reduz de 18 para 16 anos a maioridade penal no país. O texto, do Senador Demóstenes Torres (Democratas (DEM)GO), propõe a redução, mas estabelece o regime prisional somente para jovens menores de 18 anos e maiores de 16 que cometerem crimes hediondos. Cf. Guerreiro (2007).
}

aprovou a redução da maioridade penal, de 18 para 16 anos $^{5}$.

\section{AS AMBIGUIDADES ENTRE O DISCURSO PENAL E O ESTADO PUNITIVO NO BRA- SIL}

Sob essa perspectiva liberal, assente em nossa democracia tutelada, o discurso jurídico corrente após a redemocratização do país aponta para a busca de uma eficácia maior do sistema penal que seja, ao mesmo tempo, capaz de garantir a consolidação da democracia - por meio do respeito às garantias individuais presentes na Constituição. Mantendo essa contradição, a Justiça Penal brasileira atua de forma ambígua, propagando incessantemente sua democratização, mas cumprindo a lei de maneira tortuosa e agindo, assim, de forma autoritária e seletiva. Particularmente nosso discurso penal hegemônico congrega elementos absolutamente contraditórios, como repressão severa e penas alternativas, leis duras e garantias processuais, encarceramento em massa e proteção aos direitos humanos.

Ao observarmos, por exemplo, a declaração do Desembargador do Tribunal de Justiça de São Paulo, Sebastião Luiz Amorim (2006), também presidente da Associação Paulista de Magistrados (Apamagis), de que "se a população clama por penas mais rígidas, cabe ao Congresso modificar a legislação penal”, verificamos o apoio a um controle autoritário. O Desembargador, que se diz um “cidadão eminentemente democrata”, clama para que o Congresso Nacional promulgue leis em acordo com a vontade popular, afirmando que "tempos duros exigem leis duras"6.

Ao referir-se à vontade popular soberana para legitimar sua postura autoritária, esse jurista acaba por forjar um discurso falsamente democrático, submetendo a vontade geral à sua em particu-

\footnotetext{
5 Ressalta-se que, por tratar-se de emenda à Constituição, para virar lei, a proposta ainda deverá ser discutida amplamente e votada nas duas casas do Congresso Nacional.

${ }^{6}$ Contestando tal declaração, o Juiz Marcelo Semer (2006) destaca que o incremento da violência estatal não pode ser considerado filho direto da impunidade, mas, ao contrário, fruto da própria punição. Segundo Semer, “a experiência tem reiteradamente mostrado que a expressão costuma ser invertida: penas mais rígidas é que tornam os tempos mais duros”.
} 
lar e também à de uma elite, a qual ele representa. Isso acontece graças à nossa fragilidade civil ou, como prefere O’Donnell (1999, p. 31), a uma cidadania de "baixa intensidade" , capaz de permitir que os anseios populares sejam facilmente manipulados, tornando extremamente paradoxais as expectativas do cidadão junto às instituições como a polícia e o poder Judiciário.

Aqui cabe a observação gramsciana de que o maior desafio das classes populares é conquistar democraticamente as instituições capazes de fazer emergir uma sociedade civil crítica, participativa e que exerça sua cidadania de forma coerente. É justamente essa competência cívica que os regimes autoritários procuram evitar, e o poder Judiciário, muitas vezes, contribui para esse processo, ao se comportar, por exemplo, como o Desembargador acima citado.

Discursos como o dele ocultam o autoritarismo que se deseja manter por meio de uma demagógica defesa democrática da segurança coletiva e individual. Produtos de uma sociedade hegemonicamente egoísta e maniqueísta, e de um campo elitista e conservador, "muitos magistrados brasileiros tendem a usar suas sentenças como instrumento de uma exigida faxina social”. Esse diagnóstico foi feito pelo próprio presidente do Tribunal de Alçada Criminal de São Paulo, José Renato Nalini (2004), que reconheceu integrar “uma minoria no Judiciário” e defendeu alterações profundas no processo de formação dos juízes.

E essa é uma realidade que não está restrita à magistratura, mas que, na verdade, abarca todo o campo jurídico. Juízes, delegados e promotores de justiça mantêm viva a chama autoritária, agindo como se fossem os guardiões da lei e da ordem. Sob esse emblema, passam a combater a impunidade defendendo a aplicação de penas severas, representadas quase sempre por longas privações de liberdade. Também se mostram cada vez mais omissos frente às práticas ilegais de repressão, como, por exemplo, a violência policial.

\footnotetext{
7 A cidadania de baixa intensidade é justamente aquela associada apenas ao sufrágio, ou seja, o indivíduo entende como cidadania apenas o direito de votar em seus governantes. Para que exista cidadania plena, todavia, é necessário haver um mínimo de competência cívica, ou seja, uma sensação de que se é capaz de influenciar no processo de decisão das políticas públicas (PINHEIRO et alii, 1999, p. 37).
}

Situação semelhante é a inércia do poder Judiciário e do Ministério Público frente ao descaso estatal com o nosso sistema penitenciário, que se encontra em condições precárias e desumanas. Nessas ocasiões, o princípio da legalidade cai por terra e tanto o guardião (o poder Judiciário) como o fiscal da lei (o Ministério Público) contentam-se em responsabilizar o poder Executivo.

Aliás, mesmo aqueles engajados no "movimento garantista", e por isso considerados "mais democráticos”, articulam sua retórica baseados, em grande medida, apenas na predominância da lei, a fim de impedir as arbitrariedades do Estado. Segundo Amaral Jr. (2005), para esse movimento, "o Direito Penal encontra sua justificação no realizar sua missão de regular a vida social de forma ativa, protegendo a sociedade mediante normas preventivas e ajustadas ao sentido e limites de um Estado Democrático de Direito. O Direito Penal serve simultaneamente para limitar o poder de intervenção do Estado e para combater o crime”.

No contexto jurídico-penal atual, quando se fala em garantismo, pensa-se logo no conceito de Estado de Direito, modelo jurídico destinado a limitar e evitar a arbitrariedade do poder estatal. Realmente, representou o "garantismo penal” um movimento teórico fundado na radicalização das idéias do Iluminismo. Encabeçado por Luigi Ferrajoli (2002), tal movimento parte da idéia, já presente em Locke e em Montesquieu, de que do poder há sempre que se esperar um potencial abuso, sendo, portanto, necessário neutralizá-lo com o estabelecimento de um sistema de garantias, limites e vínculos ao poder de controlar. As garantias penais (taxatividade, igualdade, estrita legalidade etc.) e as garantias processuais (presunção de inocência, in dubio pro reo, publicidade, devido processo legal etc.) seriam as técnicas para tornar efetiva essa exigência de redução de violência e domínio punitivo (cf. STIPP, 2006).

Seus seguidores preocupam-se, portanto, em resguardar o indivíduo do poder estatal e de seus abusos, por meio do reconhecimento de direitos e garantias materiais e processuais contidas na norma. De fato, seu idealizador, o jurista italiano Luigi Ferrajoli resume seu modelo teórico como aquele orientado pela normatividade: "Graças ao sistema, ou modelo, garantista, o Direito contemporâneo não programa somente as suas formas de produção através de normas procedimentais sobre a formação das leis e dos outros atos normativos. Programa 
ainda os seus conteúdos substanciais, vinculandoos normativamente aos princípios e valores inscritos nas constituições, mediante técnicas de garantia que é a obrigação e responsabilidade da cultura jurídica elaborar” (FERRAJOLI, 1997, p. 94).

Nas palavras do Procurador de Justiça João Marcello de Araujo Júnior: "O atual sistema garantista, além das idéias nucleares fundadas nos princípios da culpabilidade, da previsibilidade, da segurança jurídica, da humanidade da pena, da igualdade, da proporcionalidade, parte da aceitação de que a legitimação da atuação do Direito Penal decorre, basicamente, da prevenção geral do delito, desde que esta respeite aquelas garantias formais e materiais que são próprias do Estado Democrático Social do Direito. O garantismo dos nossos dias entende que o Direito Penal somente se legitima para atuar sobre o estado de liberdade do indivíduo, se agir sob um rigoroso controle do poder do Estado" (Araujo Júnior apud NOGUEIRA DA GAMA \& GOMES, 1999).

Essa mesma compreensão legalista é compartilhada pelo advogado Salo de Carvalho (1999, p. 4-5): "O modelo garantista recupera a funcionabilidade da pena na restrição e imposição de limites ao arbítrio sancionatório judicial e administrativo. [...] A pena se apresenta como guardiã do direito do infrator em não ser punido senão pelo Estado, redimensionando a função do direito e do processo penal. Impedir o mal da arbitrariedade desmedida operada pelo ébrio desejo de vingança da vítima, ou pelas forças solidárias a ela, bem como o excesso punitivo (de violência) do Estado, é o escopo deste novo modelo de direito penal. As garantias são, portanto, instrumentos de restrição da violência e do poder punitivo: limitação dos tipos penais, do arbítrio dos julgamentos e da aflitividade das sanções. [...] Garantismo - como leciona Luigi Ferrajoli - significa precisamente 'a tutela dos direitos fundamentais cuja satisfação, ainda que contra os interesses da maioria é o escopo justificante do direito penal: imunidade do cidadão contra a arbitrariedade das proibições e das punições, defesa dos fracos mediante regras do jogo iguais para todos, dignidade da pessoa do imputado e, portanto, garantia de sua liberdade' [sic]”.

Fica nítido que ao defenderem a legalidade posta, afirmando a importância da interpretação de toda e qualquer lei conforme a Constituição (texto legal que reúne as garantias individuais do cidadão), eles continuam a operar frente às utopias liberais contidas nas normas. Segundo Miriam
Guindani (2006), certos teóricos ${ }^{8}$ chamam a atenção para a filiação liberal do garantismo e afirmam que seu radicalismo tem pés de barro. Para justificar essa crítica, partem da premissa de que a consolidação democrática "exige muito mais do que o samba-de-uma-nota-só das garantias dos direitos individuais, constitucionalmente consagrados, por mais que eles sejam sagrados e devam ser respeitados".

Talvez se possa discutir, inclusive, que a manutenção do Estado, com a simples defesa das propostas garantistas, "seria mais uma armadilha para manter a ordem como está, com suas desigualdades sociais e, assim, legitimar - novamente - o discurso jurídico como o garantidor dos interesses das classes dominantes" (WUNDERLICH, 2002, p. 46). Isso nos remete ao espirituoso comentário feito por Nilo Batista, em um seminário realizado em 2003, no Centro de Estudos Judiciários. Segundo o jurista: "O primeiro Heleno Fragoso afirmava que o Direito Penal se incluía 'entre as ciências culturais, conforme a classificação que provém da filosofia dos valores', e frisava que 'não é missão do jurista estudar a realidade social para estabelecimento de conceitos'. O penalista seria, assim, meio parecido com o personagem da anedota, aquele paciente que, após três lustros de psicanálise, recebe alta e, encontrando na rua um amigo que lhe pergunta como vai, responde com um esgar: eu vou muito bem, a realidade é que é insuportável” (BATISTA, 2003a).

Nesse sentido, o movimento garantista, dentro da Ciência Penal, pode ser comparado a uma reivindicação, até certo ponto inócua, de setores menos conservadores do campo jurídico. Enquanto atitude ético-política que centra o discurso jurídico na reivindicação de direitos, de liberdades e de garantias, tal movimento preocupa-se mais em alardear suas convicções, sem, contudo, realizálas. A prática - vale dizer, o compromisso com a mudança real de comportamento do campo jurídico, inclusive rompendo com as abstrações liberais contidas na lei - não se destaca nesse movimento. O garantismo inscreve-se, portanto, nesse universo discursivo que timidamente propugna pela consolidação democrática por meio, simplesmente, do respeito à Constituição.

8 Na Itália, destaca-se a crítica de Rosella Selmini, e, no Brasil, a de Luis Eduardo Soares. Sobre o tema, ver Soares (2005). 
Enfim, mesmo tal discurso, que em matéria penal apresenta-se como democrático e humanista, promove sua defesa preponderantemente no âmbito formal. Daí a função alegórica que desempenha tal movimento na defesa da cidadania, permitindo, inclusive, a continuidade da própria "democracia tutelada" que estamos, no momento, a evidenciar. Tratando-se de um discurso pouco combativo, acaba por reduzir a crítica ao sistema penal, reificando mais uma vez a norma e abafando movimentos genuinamente contrahegemônicos. Tudo leva a crer que de boas intenções o campo jurídico também deva estar cheio.

Apesar da defesa constante da obediência aos princípios garantidores, isto é, àqueles que, em tese, resguardariam o cidadão das arbitrariedades estatais, a prática vigente do sistema penal convive, por exemplo, com prisões precárias e superlotadas, cuja clientela é quase exclusivamente composta por pobres. A verdade é que a distância entre garantias constitucionais e a aplicação do direito ordinário é enorme, e o campo jurídico tem sido desidioso em tentar encurtá-la. Como bem ressalta Guindani (2006), “as estruturas nas quais a teoria penal está inserida, tratam de neutralizar tais discursos, ou deixar uma margem bastante elástica de manobra, a fim de que eles sejam aplicados discricionariamente”.

Aqueles que corajosamente transcendem o mero discurso, atuando efetivamente na realização das garantias individuais, acabam condenados publicamente pela mídia e punidos pelas próprias corporações a que pertencem. É o que se pode depreender do episódio ocorrido em Minas Gerais, envolvendo decisões judiciais contrárias a essa tendência autoritária e que, zelando pelo cumprimento da lei, fizeram valer os princípios garantistas presentes na Constituição.

Tais decisões, proferidas em Contagem (região metropolitana de Belo Horizonte), no final de 2005, foram responsáveis por libertar mais de cinqüenta presos, devido à falta de condições carcerárias. A soltura desses presos imediatamente provocou a total indignação da sociedade civil e do sistema penal mineiro. O Juiz da Vara de Execuções Criminais, Livingsthon José Machado, superando o mero discurso garantista e agindo de forma comprometida com a consolidação democrática, expediu alvarás de soltura para presos provisórios das carceragens dos distritos policiais da cidade. Machado alegou que a falta de con- dições dos locais desrespeitava a Constituição e a Lei de Execução Penal ${ }^{9}$. Citou ainda um laudo da Vigilância Sanitária que havia constatado a disseminação, nos locais, de doenças sexualmente transmissíveis, tuberculose e hepatite.

Contudo, suas decisões foram rapidamente reformadas através de liminar concedida pelo Desembargador Paulo Cézar Dias, do Tribunal de Justiça do Estado. O Desembargador atendeu a um pedido do governo mineiro em mandado de segurança e alegou que a libertação dos presos teria causado "grave risco à segurança pública" (GUIMARÃES, 2005). Uma semana depois de determinar a libertação desses presos, o Juiz voltou a adotar a medida. Machado mandou soltar 36 presos do $2^{\circ}$ Distrito Policial. A decisão agitou novamente o governo mineiro, a ponto do Governador Aécio Neves vir a público acusá-lo de "promoção pessoal”. Aécio considerou a decisão "irresponsável", por "colocar em risco a vida de pessoas de bem”, e “inócua”, por não resolver o "problema crônico do déficit de vagas no sistema penitenciário" (PEIXOTO, 2005a). Nova liminar do Tribunal foi expedida suspendendo a decisão do juiz e, ao contrário da primeira vez, quando 16 presos foram postos na rua imediatamente, a polícia os manteve na cadeia até a chegada da liminar.

A Corregedoria do Tribunal mineiro também proibiu o Juiz de emitir novos alvarás e abriu procedimento disciplinar contra ele. A Procuradoria Geral de Justiça também instaurou uma comissão, formada por nove promotores, para apurar se o Juiz havia prevaricado. Machado agiu no cumprimento da lei, fazendo valer os princípios garantistas presentes na Constituição. No entanto, mesmo agindo de acordo com a lei, ele foi acusado de prevaricação ${ }^{10}$ e afastado pela Corte Superior do Tribunal de Justiça de Minas Gerais,

9 É notório que as condições de encarceramento nas penitenciárias e nas cadeias violam praticamente todos os direitos dos presos, relacionados no artigo $5^{\circ}$ da Constituição Federal e reafirmados na Lei de Execuções Penais (Lei n. 7 210/84), que estabelece critérios de higiene, salubridade e dignidade ao longo do cumprimento da pena.

10 Art. 319 do Código Penal: "Retardar ou deixar de praticar, indevidamente, ato de ofício, ou praticá-lo contra disposição expressa de lei, para satisfazer interesse ou sentimento pessoal” (PRESIDÊNCIA DA REPÚBLICA. CASA CIVIL. SUBCHEFIA PARA ASSUNTOS JURÍDICOS, 1940). 
que também instaurou processo administrativo contra o Juiz. Ainda segundo a Corte Superior, o Juiz estaria sujeito às seguintes punições: aposentadoria compulsória, remoção para outra comarca ou até mesmo demissão (PEIXOTO, 2005b).

$\mathrm{O}$ ato isolado e corajoso desse Juiz chama a atenção para a persistência autoritária do Estado, que, ao impingir condições desumanas aos detentos, age em flagrante desobediência à lei. $\mathrm{O}$ descumprimento dessa norma pode ser traduzido como dupla punição ao condenado, constituindo ilegalidade inaceitável, pois usurpa do cidadão a proteção contra as arbitrariedades estatais.

É assim que caminha a Justiça Penal, vale dizer, para a consolidação do "Estado punitivo", voltado para a defesa da lei e da ordem liberal, materializado no encarceramento em massa e ilegal de membros das classes populares. Nesse enredo socioeconômico e cultural cada vez mais evidente no Brasil, a própria Justiça é também o retrato da adesão às premissas liberais refletidas no excessivo, desumano e desigual tratamento penal. A própria decisão do Tribunal de impedir Machado de expedir novos alvarás de soltura é outro exemplo de autoritarismo. Ela afigura-se como um ato manifestamente inconstitucional, pois o Tribunal não pode simplesmente impedir um Juiz de julgar por não aprovar suas decisões. A independência do Juiz no exercício da judicatura, garantia formal de uma Justiça Penal democrática, foi rapidamente extirpada para tranqüilizar a sociedade.

Tal violência institucional, conduzida pela ideologia de "tranqüilização da vida social”, é efetivamente o estratagema encontrado atualmente para camuflar a desigualdade e sufocar os anseios daqueles que contrastam da ordem liberal. Essa reação contrária do campo jurídico à atitude quixotesca do Juiz mineiro escancarou, por exemplo, o desinteresse de muitos juristas em saber o que acontece no interior das prisões brasileiras, como se os muros das unidades prisionais conseguissem estancar, definitivamente, a perversidade do controle social empregado ${ }^{11}$.

11 Contudo, as humilhações e os maus-tratos impostos aos condenados, ao arrepio da lei, já estão transbordando os muros da prisão e atingindo a todos, na forma de rebeliões e ataques organizados nas ruas das grandes cidades.

\section{O ESTADO PUNITIVO E AÉTICA LIBERAL}

Nesse momento, é importante observar que a ética liberal atual ainda insiste na velha máxima de que todos nós somos seres livres e racionais, tomando nossas decisões a partir de um amplo espectro de opções: "Para pequena e ampla burguesia isso significa dedicação ao trabalho, ao lazer, às compras e à prosperidade, sem culpa, pois estão liberadas pela crença de que os indivíduos são livres e independentes, cada qual responsável por seus atos e tragédias” (SOUZA, 2003).

As classes populares também seriam livres para fazer suas escolhas e, dentro dessa perspectiva, o crime também é visto como uma escolha racional. Essa é inclusive a opinião externada pelo Juiz Luiz Ambra, do Tribunal de Alçada Criminal de São Paulo12: "Continuo entendendo o que sempre entendi, quando da passagem do fechado para o semi-aberto: não há vaga? O criminoso que se dane. [...] Simples aplicação da teoria do 'risco profissional', bem exposta pelo eminente Juiz Corrêa de Moraes, desta Câmara. Ao adotar o crime como profissão, em outras palavras, como em qualquer atividade, sujeita-se o delinqüente a riscos que lhe são inerentes. Dela fazem parte, em algumas das 'empreitas' não ser bem-sucedido, levar um tiro e morrer, ser preso, na cadeia não receber o tratamento 'à altura' de que se julgar merecedor, passar à promiscuidade com outros detentos, por eles ser seviciado e estar sujeito a abusos sexuais" (SÃO PAULO. TRIBUNAL DE ALÇADA CRIMINAL. SÉTIMA CÂMARA, 2002).

Tal premissa permite aumentar a atuação da Justiça Penal e a severidade das punições aplicadas, camuflando a seletividade do sistema nas tão conhecidas ficções liberais de igualdade de oportunidade e liberdade de escolha: "Acreditar que o crime é uma decisão, dá apoio à ficção necessária da economia de mercado segundo a qual a prosperidade e a pobreza são conquistas de indivíduos, não são condicionantes de raças, classes ou gêneros, bem como nenhuma pessoa é responsável pela dificuldade de outras ou obrigada a confrontar deficiências estruturais no sistema” (SOU$\mathrm{ZA}, 2003)$

12 Manifestação externada no Voto n. 9388, em decisão sobre o pedido de Habeas Corpus n. 402 314/6, impetrado perante o Tribunal de Alçada Criminal de São Paulo. 
Tal pressuposto, portanto, também estabelece a seletividade do sistema penal assente no atual "Estado punitivo". No Brasil, tal fato já havia sido abordado por Ruben Oliven (1981, p. 28), no começo dos anos 1980. No artigo Chame o ladrão: as vítimas da violência no Brasil, o autor alertava para o fato de que os grupos dominados eram, freqüentemente, muito mais vítimas do que responsáveis pela violência criminal em nossas cidades, embora fossem os mais perseguidos pela Justiça Penal e os que mais recebiam punições.

Isso demonstra que a história do Brasil é uma combinação permanente e alternada de paternalismo e repressão (FIORI, 1995). No atual contexto liberal, tal repressão ganha novos contornos, mas o alvo continua sendo o refugo social que sempre possuímos.

Todos esses fatores, considerados em conjunto, convergem para a compreensão burguesa que identifica a prática do crime somente pelos “desclassificados”, o que resulta praticamente na “criminalização da pobreza” (BAUMAN, 1999, p. 134). Efetivamente, a percepção do crime está diretamente influenciada pelo uso que as elites fazem dos aparelhos judiciais. Há uma confluência entre os alvos da insegurança e as políticas judiciais que, em sua grande maioria, se concentram nos crimes contra o patrimônio. Por outro lado, conforme afirma Pinheiro (1997): "Se levarmos em conta a maioria esmagadora dos processos e dos condenados pela Justiça, teremos fundamentalmente aqueles delitos praticados pelas classes populares".

Nosso próprio ordenamento penal está impregnado de valores burgueses que refletem exatamente essa dominação. Há em nossas leis profundos ataques aos princípios democráticos e que representam formas de desrespeito à cidadania e à dignidade humana. Apenas para ilustrar: nossa legislação penal prevê uma pena de oito a quinze anos de reclusão para aquele que, por menos de vinte e quatro horas, seqüestrar pessoa com o fim de obter qualquer vantagem, como condição ou preço do resgate (art. 159 do Código Penal) (PRESIDÊNCIA DA REPÚBLICA. CASA CIVIL. SUBCHEFIA PARA ASSUNTOS JURÍDICOS, 1940). Absurdamente, nosso mesmo ordenamento estabelece uma pena bem inferior (reclusão de um a três anos) para aquele que, sem exigir qualquer vantagem, mantém alguém, indefinidamente, em cárcere privado (idem, art. 148). Outro absurdo, que escancara tal dominação classista presente em nossa legislação, é a pena prevista para quem reduz alguém à condição análoga à de escravo. Segundo o Código Penal (idem, art. 149), reduzir alguém à condição análoga à de escravo, quer submetendo-o a trabalhos forçados ou à jornada exaustiva, quer sujeitando-o a condições degradantes de trabalho, quer restringindo, por qualquer meio, sua locomoção em razão de dívida contraída com o empregador ou preposto, sujeita o criminoso a uma pena de reclusão de dois a oito anos.

Composto, em sua maioria, por penas que importam encarceramentos longos e degradantes, principalmente para os crimes contra o patrimônio (praticados majoritariamente pelas classes populares), nosso ordenamento está longe de representar um Estado democrático. Ainda assim, é considerado pelo próprio "operador do Direito" como inócuo, pois ainda não aniquila totalmente o infrator. Ainda mais se levarmos em consideração que os meios de comunicação de massa, inseridos também no discurso liberal hegemônico, bloqueiam qualquer debate possível entre a criminologia minimalista - que defende a redução da intervenção penal no controle social - e a sociedade civil. De acordo com Nilo Batista (2003b, p. 3-6): “O novo credo criminológico da mídia tem seu núcleo irradiador na própria idéia de pena: antes de mais nada, crêem na pena como rito sagrado de solução de conflitos.[...] Não há debate, não há atrito: todo e qualquer discurso legitimante da pena é bem aceito e imediatamente incorporado à massa argumentativa dos editoriais e das crônicas. [...] Neste sentido, toda e qualquer reflexão que deslegitime aquele credo criminológico da mídia deve ser ignorada ou escondida: nenhuma teoria e nenhuma pesquisa questionadora do dogma penal, da criminalização provedora ou do próprio sistema penal são veiculados em igualdade de condições com suas congêneres legitimantes [sic]”.

Assim, imersos na concepção hegemônica de Justiça Penal como único caminho de controle das “desordens” causadas pela intensificação das mazelas sociais no contexto atual, nossos "operadores do Direito", como gostam de ser chamados, agem como os novos faxineiros da modernidade. Para Sérgio Adorno, entre os juízes, "salvo exceções, predominam os interesses mais conservadores no tocante ao controle da ordem social, à contenção repressiva dos crimes e ao trato nas questões de segurança pública”. Mesmo quando 
toleram falar em direitos humanos, desconfiam com freqüência das soluções alternativas e da aposta em políticas democratizantes: "ao contrário, enfatizam as políticas retributivas, que apliquem maior rigor punitivo, se possível concentradas em penas restritivas de liberdade" (ADORNO, 2000, p. 149).

Confirmando tal análise, um balanço realizado pela Central Nacional de Apoio e Acompanhamento às Penas e Medidas Alternativas (Cenapa), órgão vinculado ao Ministério da Justiça, atestou, no ano de 2003 , que as penas alternativas ${ }^{13}$, recomendadas para crimes de pequena e média gravidade, beneficiavam apenas $8,7 \%$ dos infratores do país ${ }^{14}$. Em alguns estados, no entanto, não se chegava nem a esse percentual: em São Paulo, por exemplo, as penas beneficiavam apenas 1,3\% dos infratores (IWASSO, 2003). Não existia, na época (e não existe ainda hoje), um estudo mostrando quantos presos poderiam estar fora do cárcere, cumprindo essas penas, mas, segundo Maria Eli Bruno, coordenadora do Cenapa paulista, cerca de $10 \%$ dos presos de São Paulo poderiam, no ano de 2003, estar cumprindo outro tipo de pena (idem).

Dados da Secretaria de Administração Penitenciária de São Paulo atestavam também, em 2004, que muitos criminosos eram condenados pelos juízes a regimes mais severos de cumprimento de pena do que os previstos na lei. Naquele momento, de cada dez presos condenados por roubo no estado, sete deles teriam que cumprir penas fixadas próximas ao mínimo legal e seriam réus primários. Em tese, portanto, atendiam às primeiras exigências impostas para a concessão do regime semi-aberto. Na prática, contudo, os números eram bem diferentes. A análise identificava 24619 condenados por roubo cumprindo pena em regime fechado no estado $(23,56 \%$ do

13 Uma mudança na legislação, em 1998, feita pela Lei n. 9714/98, passou a permitir que os condenados a até quatro anos de prisão, cujo crime não tenha envolvido violência, tenham a pena de prisão convertida para uma punição alternativa. Entre elas estão as restritivas de direitos, as de prestação de serviços à comunidade e as pecuniárias.

14 De acordo com o Juiz Ali Mazloum, então lotado na $7^{\mathrm{a}}$ Vara Federal Criminal de São Paulo, cerca de 50\% das ações penais, na esfera federal, permitiam que fossem aplicadas as penas alternativas. O Juiz estimava também que, na esfera estadual, esse percentual poderia chegar a $60 \%$. Ver Iwasso (2003). total de 104488 presos, para 79629 vagas). Roubo, que não é crime hediondo, não exige condenação direta ao regime fechado, no entanto, só 4 519 (18\%) estavam em semi-aberto (CORRÊA, 2004).

Esses índices mostram que nossa Justiça Penal está impregnada da idéia de encarcerar, mesmo que isso não tenha reflexos na diminuição da criminalidade. Ao contrário, nosso sistema prisional, tradicionalmente degradante e estigmatizante, serve mais como ponto de reunião, organização e difusão da criminalidade em larga escala. Ainda em 2004, um levantamento feito pelo Instituto de Defesa do Direito de Defesa (IDDD) ${ }^{15}$ constatou que, em $81,5 \%$ das condenações por roubo analisadas, os juízes fundamentavam a opção pelo regime fechado, citando argumentos genéricos como a gravidade do delito, a periculosidade do agente e a necessidade de defesa da sociedade. Utilizavam-se de frases como: "o crime é grave", "o autor de roubo é perigoso" e "o roubo desassossega a sociedade" (idem).

Para o IDDD, as decisões seriam ideológicas e sustentadas em argumentos extralegais: "Se na maioria dos casos a pena base é fixada no mínimo, isso nos leva a crer que o juiz não encontrou circunstâncias legais para agravá-la. Então, de onde ele tira argumentos para endurecer o regime? De uma esfera de extralegalidade”, afirmava a advogada Fernanda Vargues Martins, então vicepresidente do Instituto. É o que se pode depreender da fala do Promotor de Justiça Carlos Cardoso: para ele, "o semi-aberto tem de ser reservado a criminosos que não tenham revelado insensibilidade moral, e esse não seria o caso de condenados por roubo". Para o Promotor, o que o Instituto chamava de extralegal estava inserido na "margem de discricionariedade do juiz": "Está corretíssimo o juiz que diz que o roubo desassossega. Ele está apenas ponderando as conseqüências do crime e de sua decisão” (idem).

Contestando essa vertente, Celso Limongi, então Presidente do Tribunal de Justiça de São Paulo, advertia que sentenças como essas refleti-

15 Criado em 2000, o IDDD congrega 109 advogados do país e tem como objetivo a ampliação do direito de defesa e a resistência ao recrudescimento penal. Um dos seus fundadores é o atual Ministro da Justiça, Márcio Thomaz Bastos, que lançou a idéia de revisão da Lei de crimes hediondos. 
am "um erro científico": "Todo mundo vive assustado e aí se supõe que a lei mais dura possa dissuadir alguém do crime. Isso não é verdade”, dizia Limongi, que defendia que esse rigor deveria ser "mitigado caso a caso". Para o Desembargador, "a Justiça tem de ser de caso concreto, não de generalizações”, afirmando a necessidade de se "pedir aos juízes que reflitam” (idem).

Mais do que um erro científico, essa política de esvaziar as ruas de criminosos, que agridem principalmente a propriedade privada, pode ser traduzido como uma nova cruzada moral burguesa, de forte conteúdo autoritário, baseada não apenas na mera sensação de impunidade, mas, sobretudo, na necessidade liberal de criar ambientes seguros para o consumo e para o investimento.

Durante a execução da pena, o endurecimento também se manifesta, ainda que em dissonância com a legislação. Essa foi a constatação da pesquisa realizada pela Fundação Seade, no ano de 2002, no universo dos processos de execução criminal da Vara das Execuções Criminais da capital paulista ${ }^{16}$. Segundo a pesquisa:

“Com referência à progressão de regime, o primeiro resultado obtido indica que $22,1 \%$ de presos obtiveram a progressão de regime (com margem de erro 4\%). Deste modo, apenas uma pequena parte da população carcerária logra cumprir sua pena de modo progressivo, muito embora a progressividade seja o modelo geral adotado pela LEP e pela Constituição Federal [...]. Outra informação reveladora é que $72,5 \%$ das pessoas que obtiveram a progressão haviam cumprido mais de um terço da pena. Por esse dado infere-se que, da pequena parte dos presos que obtém a progressão de regime, a maioria só a alcança com o cumprimento do prazo muito acima do legal (um sexto), o que demonstra que este não é balizador das decisões dos juízes. [...] Em relação ao livramento condicional, observou-se que $8 \%$ de presos obtiveram este benefício (margem de erro 3\%). [...] Esse dado aponta para uma parcela muito pouco significativa da massa carcerária que realmente chega a alcançar o benefício. Note-se que seu percentual é ainda inferior ao dos que obtêm a progressão de regime" (BORDINI \& TEIXEIRA, 2004).

16 Para mais informações sobre o tema, conferir Bordini e Teixeira (2004).
Pelo que se observa, a Justiça Penal, mesmo durante a execução da pena, opera de forma autoritária e excludente, ao suprimir ao máximo os direitos previstos em lei para os condenados, adotando uma postura altamente repressiva, revelada pelos ínfimos percentuais de benefícios ${ }^{17}$ concedidos. Orientado pela via da segregação penal, está assumindo, nosso poder Judiciário, a tese hegemônica que conclama a maior punição como meio legítimo de controle social. Agindo assim, nossos juízes não só promovem o confinamento violento das classes populares como contribuem para o "reforço de atitudes de cinismo e descrença frente à competência de modelos democráticos de resolução de conflitos" (BEATO \& PAIXÃO, 1997, p. 2).

\section{CONCLUSÃO}

No Brasil, as respostas à criminalidade consistem, portanto, em sua grande maioria, em penas severas, traduzidas na ausência do respeito às garantias constitucionais e no recurso amplo ao encarceramento. Nessa linha, nossos governos

17 Entre os benefícios prisionais estão as progressões de regime, o livramento condicional, a autorização de saída temporária, entre outros, todos previstos na Lei de Execução Penal (Lei no 7210/84). A legislação penal determina diferentes regimes de cumprimento das penas: fechado, semi-aberto e aberto. Nos dois últimos, admite-se a possibilidade do preso trabalhar fora dos muros e visitar a família regularmente. O regime inicial de cumprimento de pena é determinado pelo tempo de condenação e pela reincidência ou não do condenado. Ao longo de sua pena o preso pode ser beneficiado com a mudança de um regime para outro, considerando-se, para tanto, o tempo de pena já cumprido e a sua situação disciplinar. Ainda de acordo com a legislação, o regime fechado deve ser cumprido em penitenciárias, o regime semi-aberto em colônias agrícolas ou industriais, e o regime aberto em casas de albergado. $\mathrm{O}$ livramento condicional é a antecipação provisória da liberdade do condenado pelo juiz da Vara das Execuções Criminais, quando presentes determinados requisitos legais. $\mathrm{O}$ sentenciado fica sujeito a certas obrigações. Entre os requisitos indispensáveis, está o cumprimento de mais de $1 / 3$ da pena se o condenado não for reincidente em crime doloso e tiver antecedentes favoráveis. As saídas temporárias consistem em permissões judiciais para presos de boa conduta carcerária que cumprem pena em regime semi-aberto $\mathrm{O}$ próprio diretor-geral do presídio encaminha ao juiz a relação dos presos que têm direito à saída temporária. A Lei de Execução prevê saída temporária para visitar a família, que pode ser concedida cinco vezes ao ano. Cada saída poderá durar até sete dias corridos. As saídas são regulamentadas e concedidas nas seguintes datas: Natal/Ano Novo; Páscoa; Dia das Mães; Dia dos Pais e Finados. 
democráticos contemporâneos freqüentemente adotam uma posição punitiva que visa reafirmar a aptidão do Estado em punir e controlar a criminalidade.

O fato é que o Estado brasileiro percebeu que manter-se autoritário, multiplicando crimes, aumentando penas e endurecendo a execução, é expediente fácil para garantir o sucesso das políticas liberais adotadas. Diante do medo hegemônico crescente, muitas vezes amplificado pelos meios de comunicação de massa, o poder Judiciário cumpre sua função orgânica de proteger a elite que compõe, agindo com rigor no combate ao crime proveniente das classes populares. Em um ciclo vicioso, o campo jurídico passa a associar a eficiência à repressão. Muitos, inclusive, ressentemse dos limites legais que protegem os direitos dos réus e dos condenados. Encaram como uma restrição à sua prerrogativa de punir. A legitimidade, portanto, está na atuação autoritária.

Nossa Justiça Penal, como não poderia deixar de ser, também reproduz essa mensagem no ideal de "ordem acima da lei". Ao eximir-se da responsabilidade de fiscalizar as condições carcerárias, e mantendo a cultura de só punir com a cadeia, o campo jurídico brasileiro realiza, com o encarceramento desenfreado e cruel, a função essencial do Estado burguês: "a garantia do sono tranqüilo do proprietário de Adam Smith e a redução do risco da morte violenta que atemorizava Thomas Hobbes" (BEATO \& PAIXÃO, 1997, p. 2).

Enfim, o que observamos atualmente é o investimento cada vez maior do Estado em ações mais duras e repressivas que privilegiam o encarceramento. Essa ampliação do controle penal reflete as transformações econômicas, sociais e culturais já em curso nos últimos trinta anos nos países alinhados com o novo modelo capitalista de desenvolvimento.

Nesse sentido, o surgimento e a consolidação do que a teoria social denominou "Estado punitivo", incorporado sempre ao tema da democracia, alçou, portanto, a questão do combate ao crime como peça do grande consenso presente na uniformização dos valores políticos, morais e sociais das sociedades contemporâneas. A defesa constante da "guerra contra o crime", agindo como elo hegemônico consensual, amplia a defasagem entre o formal e o real, bem como a utilização meramente simbólica e autoritária do Direito Penal. Nesse contexto, marcado pela incessante busca da "tranqüilização da vida social", o que se verifica é a consolidação de uma sociedade de exclusão, de uma democracia sem cidadania, de um cidadão sem direitos. Esse é também o retrato nacional.

Débora Pastana (pastana.pastana@bol.com.br) é Doutora em Sociologia pela Universidade Estadual Paulista (Unesp).

\section{REFERÊNCIAS BIBLIOGRÁFICAS}

ADORNO, S. 2000. Direito e democracia. Diálogos \& Debates, São Paulo, v. 1, p. 30-37.

AMARAL JÚNIOR, R. 2005. O Direito Penal garantista. Boletim IBCCRIM, São Paulo, v. 13, n. 153, p. 14-15, ago.

AMORIM, S. \& MORELLE, I. 2006. A verdade real. Folha de São Paulo, caderno Tendências/Debates, 1.jun. Disponível em : http:// www1.folha.uol.com.br/fsp/opiniao/ fz0106200608.htm. Acesso em : 21.jan.2009.

BATISTA, N. 2000. Prezada Senhora Viégas : o anteprojeto de reforma no sistema de penas. In : INSTITUTO CARIOCA DE CRIMINOLOGIA. Discursos sediciosos - crime, Direito e sociedade. Rio de Janeiro : Relume-Dumará.

BATISTA, N. 2003a. Novas tendências do Direito Penal. Palestra proferida no Centro de Estudos Judiciários, em 8 de maio. Disponível em : http://conline1.cjf.jus.br/phpdoc/pages/ sen/portaldaeducacao/textos_fotos/ dpenal2003/NiloBatista.doc. Acesso em : 21.jan.2009.

2003b. Mídia e sistema penal no capitalismo tardio. Revista Brasileira de Ciências Criminais, São Paulo, v. 42, jan.-mar. Disponível em : http://www.bocc.ubi.pt/pag/batista-nilomidia-sistema-penal.pdf. Acesso em : 21.jan.2009. 
BATISTA, V. M. 2001. Autoritarismo e controle social no Brasil - memória e medo. Sem Terra, São Paulo, n. 10. Disponível em : http:// www.lainsignia.org/2001/marzo/cul_040.htm. Acesso em : 20.jan.2009.

BAUMAN, Z. 1998. O mal-estar da pósmodernidade. Rio de Janeiro : J. Zahar.

1999. Globalização : as conseqüências humanas. Rio de Janeiro : J. Zahar.

BEATO, C. \& PAIXÃO, A. 1997. Crimes, vítimas e policiais. Tempo social, São Paulo, v. 9, n. 1, p. 43-52, maio.

BECK, F. R. 2004. Perspectivas de controle ao crime organizado e críticas à flexibilização de garantias. São Paulo : Instituto Brasileiro de Ciências Criminais.

BORDINI, E. \& TEIXEIRA, A. 2004. Decisões judiciais da Vara das Execuções Criminais : punindo sempre mais. São Paulo em Perspectiva, São Paulo, v. 18, n. 1, p. 66-71, jan.

CARVALHO, S. 1999. Manifesto Garantista. Informativo do Instituto Transdisciplinar de Estudos Criminais, Porto Alegre, n. 3.

CHRISTIE, N. 2002. Elementos de Geografia Penal. In : INSTITUTO CARIOCA DE CRIMINOLOGIA. Discursos Sediciosos - crime, Direito e sociedade. Rio de Janeiro : Relume-Dumará.

CORRÊA, S. 2004. Condenações por roubo ignoram regime semi-aberto. Folha de São Paulo, caderno Cotidiano, 1.set. Disponível em : http://www1.folha.uol.com.br/folha/cotidiano/ ult95u98968.shtml. Acesso em : 21.jan.2009.

DEPEN. 2008. Relatório estatístico-analítico do sistema prisional : Brasil. Brasília : Departamento Penitenciário Nacional. Disponível em : http://www.mj.gov.br/depen/services/ DocumentManagement/FileDownload. EZTSvc.asp? DocumentID $=\{10 \mathrm{E} 98216$ 4DCD-4368-B1BA-59FC2725623A \&ServiceInstUID $=\{4$ AB01622-7C49-420B9F76-15A4137F1CCD $\}$. Acesso em : 20.out.2008.

FERNANDES, F. 1987. A revolução burguesa no Brasil : ensaio de interpretação sociológica. Rio de Janeiro : Guanabara.
FERRAJOLI, L. 1997. O Direito como sistema de garantias. In : OLIVEIRA JÚNIOR, J. A. (org.). O novo em Direito e política. Porto Alegre : Livraria do Advogado.

.2002. Direito e razão : teoria do garantismo penal. São Paulo : Revista dos Tribunais.

FILGUEIRAS, L. 2006. O neoliberalismo no Brasil : estrutura, dinâmica e ajuste do modelo econômico. In : BASUALDO, E. \& ARCEO, E. (orgs.). Neoliberalismo y sectores dominantes. Tendencias globales y experiencias nacionales. Buenos Aires : Consejo Latinoamericano de Ciencias Sociales. Disponível em : http://bibliotecavirtual.clacso.org.ar/ar/ libros/grupos/basua/C05Filgueiras.pdf. Acesso em : 20.jan.2009.

FIORI, J. L. 1995. Em busca do dissenso perdido : ensaios críticos sobre a festejada crise do Estado. Rio de Janeiro : Insight.

FRADE, L. 2007. O que o Congresso Nacional brasileiro pensa sobre a criminalidade. Brasília. Tese (Doutorado em Sociologia). Universidade de Brasília.

GARAPON, A. 2001. O juiz e a democracia : o guardião das promessas. Rio de Janeiro : Revan.

GILL, S. 2005. Las contradicciones de la supremacía de Estados Unidos. In : PANITCH, L. \& LEYS, C. (eds.). Socialist Register. Buenos Aires : Consejo Latinoamericano de Ciencias Sociales.

GROS, D. B. 2003. Institutos liberais e neoliberalismo no Brasil da Nova República. Porto Alegre : Fundação de Economia e Estatística Siegfried Emanuel Heuser.

GUERREIRO, G. 2007. CCJ do Senado aprova redução da maioridade penal de 18 para 16 anos. Folha de São Paulo, caderno Cotidiano, 26.abr. Disponível em : http:// www1.folha.uol.com.br/folha/cotidiano/ ult95u134672.shtml. Acesso em : 21.jan.2009.

GUIMARÃES, T. 2005. Juiz libera condenados por más condições de carceragem em MG. Folha de São Paulo, caderno Cotidiano, 11.nov. Disponível em : http:// www1.folha.uol.com.br/folha/cotidiano/ ult95u115167.shtml. Acesso em : 21.jan.2009. 
GUINDANI, M. 2006. Sistemas de política criminal no Brasil : retórica garantista, intervenções simbólicas e controle social punitivo. Cadernos CEDES, Rio de Janeiro, n. 2. Disponível em : http://cedes.iuperj.br/PDF/cadernos/sistemas\%20politica\%20criminal.pdf. Acesso em : 21.jan.2009.

IWASSO, S. 2003. Pena alternativa só atinge 9\% dos infratores. Folha de São Paulo, caderno Cotidiano, 16.ago. Disponível em : http:// www1.folha.uol.com.br/folha/cotidiano/ ult95u80358.shtml. Acesso em : 21.jan.2009.

LAHUERTA, M. \& AGgIO, A. 2003. Pensar o século $X X$ : problemas políticos e história nacional na América Latina. São Paulo : Universidade Estadual Paulista.

LAMOUNIER, B. \& SOUZA, A. 2006. O futuro da democracia : cenários político-institucionais até 2022. Estudos Avançados, São Paulo, v. 20, n. 56, p. 44-60, jan.-abr. Disponível em : http://www.scielo.br/scielo.php?pid=S010340142006000100005\&script=sci_arttext. Acesso em : 19.jan.2009.

NALINI, R. 2004. Crime e castigo : Juiz reflete a sociedade, diz Desembargador. Folha de São Paulo, caderno Cotidiano, 1.set. Disponível em : http://www1.folha.uol.com.br/fsp/ cotidian/ff0109200402.htm. Acesso em : 21.jan.2009.

NEDER, G. 1996. Absolutismo e punição. In : INSTITUTO CARIOCA DE CRIMINOLOGIA. Discursos sediciosos - crime, Direito e sociedade. Rio de Janeiro : Relume-Dumará.

NOGUEIRADA GAMA, G. C. \& GOMES, A. F. 1999. Temas de Direito Penal e Processo Penal : em especial na Justiça Federal. Rio de Janeiro : Renovar.

O’DONNELL, G. 1999. Teoria democrática e política comparada. Dados, Rio de Janeiro, v. 42, n. 4, p. 655-690.

OLIVEIRA, F. 2000. Memórias do despotismo. Estudos Avançados, São Paulo, v. 14, n. 40, p. 59-63, set.-dez. Disponível em : http:// www.scielo.br/pdf/ea/v14n40/v14n40a07.pdf. Acesso em : 15.jan.2009.

OLIVEN, R. G. 1981. Chame o ladrão : as vítimas da violência no Brasil. In : BOSCHI, R. (org.). Violência e cidade. Rio de Janeiro : Zahar.
PEIXOTO, P. 2005a. Crise carcerária : Juiz manda soltar mais 36 detentos. Folha de São Paulo, caderno Cotidiano, 18.nov. Disponível em : http://www1.folha.uol.com.br/fsp/ cotidian/ff1811200514.htm. Acesso em : 21.jan.2009.

2005b. Justiça : Tribunal afasta juiz que soltou condenados. Folha de São Paulo, caderno Cotidiano, 24.nov. Disponível em : http:/ /www1.folha.uol.com.br/fsp/cotidian/ ff2411200510.htm. Acesso em : 21.jan.2009.

PINHEIRO, P. S. 1997. Violência e crime nas novas democracias : desafios para a próxima década. Disponível em : http://www.iesambi. org.br/sociologia/desafio_violencia.htm. Acesso em : 21.jan.2009.

PINHEIRO, P. S.; ADORNO, S.; CARDIA, N. \& POPPOVIC, M. 1999. Continuidade autoritária e construção da democracia. Projeto Integrado de pesquisa. São Paulo : USP. Disponível em : http://www.nevusp.org/ downloads/down000.pdf. Acesso em : 21.jan.2009.

PORTELLA, E. 2000. Dilemas e desafios da modernidade. Estudos Avançados, São Paulo, v. 14, n. 40, p. 116-121, set.-dez. Disponível em : http://www.scielo.br/pdf/ea/v14n40/ v14n40a12.pdf. Acesso em : 15.jan.2009.

QUARTIM DE MORAES, J. 2001. Contra a canonização da democracia. Critica Marxista, Campinas, n. 12, p. 9-40. Disponível em : http:/ /www.unicamp.br/cemarx/criticamarxista/ 01quarti.pdf. Acesso em : 19.jan.2009.

RIBEIRO, R. J. 2007. Razão e sensibilidade. Folha de São Paulo, caderno Ilustrada, 18.fev. Disponível em : http://www1.folha.uol.com.br/ folha/ilustrada/ult90u68751.shtml. Acesso em : 21.jan.2009.

SEMER, M. 2006. A duras penas. Folha de São Paulo, caderno Tendências/Debates, 18.jun. Disponível em : http://www1.folha.uol.com.br/ fsp/opiniao/fz1806200609.htm. Acesso em : 21.jan.2009.

SOARES, L. E. 2005. Legalidade libertária. Rio de Janeiro : L. Juris.

SOUZA, L. A. 2003. Obsessão securitária e a cultura do controle. Revista de Sociologia e Política, Curitiba, n. 20, p. 161-165, jun. Dis- 
ponível em : http://www.scielo.br/pdf/rsocp/ n20/n20a15.pdf. Acesso em : 15.jan.2009.

STIPP, A. 2006. Garantismo. In : ESCOLA SUPERIOR DO MINISTÉRIO PÚBLICO DA UNIÃO. Dicionário de Direitos Humanos. Disponível em : www.esmpu.gov.br/dicionario/ tiki-index.php. Acesso em : 21.jan.2009.

VIANNA, M. L. W. 1998. Aamericanização (perversa) da seguridade social no Brasil - estratégias de bem-estar e políticas públicas. Rio de Janeiro : Revan.
WACQUANT, L. 2001. As prisões da miséria. Rio de Janeiro : J. Zahar.

2004. A aberração carcerária. Le Monde Diplomatique Brasil, São Paulo, set. Disponível em : http://diplo.uol.com.br/2004-09,a988. Acesso em : 19.jan.2009.

WUNDERLICH, A. 2002. Sociedade de consumo e globalização : abordando a teoria garantista na barbárie. (Re)afirmação dos direitos humanos. In : WUNDERLICH, A. \& CARVALHO, S. (orgs.). Diálogos sobre a justiça dialogal. Rio de Janeiro : L. Juris.

\section{OUTRAS FONTES}

PRESIDÊNCIA DA REPÚBLICA. Casa Civil. Subchefia para Assuntos Jurídicos. 1940. Código Penal. Decreto-Lei n. 2 848/1940. Diário Oficial, Rio de Janeiro, 31.dez., p. 2391. Disponível em : http://www.planalto.gov.br/ ccivil_03/Decreto-Lei/Del2848compilado.htm. Acesso em : 15.jan.2009.
SÃO PAULO. Tribunal de Alçada Criminal. Sétima Câmara. 2002. Voto n. 9 388. Habeas Corpus n. 402 314/6 - Capital. Disponível em : http://www.mp.sp.gov.br/portal/page/portal/ habeas_corpus/jurisprudencias/juris_acordaos/ Progress\%C3\%A3o\%20-\%20Falta\%20 de $\% 20$ vagas $\% 20-\% 20$ preso $\% 20$ em $\%$ 20DP.htm. Acesso em : 21.jan.2009. 
JUSTICE PÉNALE AUTORITAIRE ET LA CONSOLIDATION DE L’ÉTAT PUNITIF AU BRÉSIL

\section{Débora Pastana}

La transition démocratique brésilienne, toujours en cours, affronte des difficultés énormes pour y intégrer l'action pénale. Il y a plus, les bornes au processus de démocratisation établis dans l'action de ce secteur étatique nous renvoient à l’idée selon laquelle le champ juridique est devenu imperméable aux changements démocratiques. Même si le discours actuel chez les professionnels du Droit proclame la démocratisation de la Justice Pénale, on remarque, en fait, une forte résistance du champ juridique à assumer sa responsabilité politique à l'égard de la consolidation démocratique. Cet article présente des analyses et des conclusions formulées à partir des remarques sur la Justice Pénale brésilienne et qui ont originé le mémoire intitulé « Justice Pénale au Brésil actuel : discours démocratique - pratique autoritaire ». L'objectif de cette recherche fut de réflechir sur la politique criminelle contemporaine, tournée vers l'élargissement de la répression et au recours à l’incarcération. Une telle politique, menée au Brésil après l'ouverture politique survenue en 1985, s'adapte au projet libéral qui est aussi en cours dans le pays et dans presque tout l'occident capitaliste. Comme on le remarque, la Justice Pénale, même pendant l'accomplissement de la peine, opère de façon autoritaire et excluante, quand elle élimine au maximum les droits prévus par la loi à l'égard des criminels condamnés, en adoptant une attitude fort répressive, qui se revèle par les infimes pourcentages d'avantages accordés. Donc, au Brésil, les réponses à la criminalité souvent consistent en des peines sevères, traduites dans le manque de respect aux garanties constitutionnelles et dans le recours excessif à l'incarcération. Dans cette ligne, nos gouvernements démocratiques contemporains adoptent souvent une position punitive visant réaffirmer la capacité de l'État de punir et contrôler la criminalité.

MOTS-CLÉS : contrôle pénal ; incarcération ; démocratie en tutelle ; État punitif ; Sociologie de la Violence.

\section{PRESSE POLITIQUE ET PENSÉE RÉPUBLICAINE DANS L’ÉTAT DU PARANÁ À LA} FIN DU XIXÈME SIÈCLE

\section{Amélia Siegel Corrêa}

La crise du régime monarchique brésilien fut suivie de l'avènement et de l'expansion du mouvement républicain, à la fin du XIXème siècle. Dans cette période, la presse non seulement est devenue la scène des débats institutionnels, mais encore a joué le rôle de pouvoir informel, lié au gouvernement et à l'organisation des partis. Il s'agissait d'une presse d'opinion, ayant comme l'un de ses axes les commentaires partisans. Les colonnes des journaux servaient à écrire de façon anonyme ce qu'on ne pouvait dire publiquement à l'Assemblée Législative, au Sénat ou dans la Chambre des Députés, ce qui constituait un forum de discussion alternatif à la tribune. Cet article cherche à reprendre les modèles de République qui ont circulé dans ces magazines de l'état du Paraná, les mettant en rapport aux configurations dans lesquelles ils étaient incorporés et à la position qu'ils occupaient dans le domaine du pouvoir local et national. Néanmoins, il faut se souvenir que les idéaux républicains prédominants ne se sont pas répandus sans résistance dans l'état du Paraná ; au contraire, ils ont été détectés et combattus sur place, mais sans assez de force politique. Nous nous appuyons sur la perspective bourdieusienne selon laquelle les discours ne sont pas uniquement signes destinés à être compris et déchiffrés, mais qu'ils sont également indices de statut, qui voudraient être valorisés et appréciés, et d'autorité, à être reconnus et obéis, puisqu'ils constituaient un objet de lutte symbolique pour le pouvoir. L'analyse des discours républicains montre que la politique de l'état du Paraná à la fin du XIX ${ }^{\text {ème }}$ siècle était plutôt des résultats des alliances et des désaccords entre groupes que le fruit de position idéologique. Les discours servaient, généralement, à être des armes rhétoriques utilisées pour orienter l'affrontement inter-élites, poussé par le désir de participation, ce qui lui a 
donné une caractéristique générale, appuyée sur la conception de fin de priviléges, néanmoins sans l'élargissement de la citoyenneté.

Mots-clés : républicanisme ; Paraná ; presse politique ; fédéralisme ; groupe politique.

PRODUCTION LÉGISLATIVE ET CONNEXION ÉLECTORALE DANS L’ASEMBLÉE LÉGISLATIVE DE L'ÉTAT DU PARANÁ

\section{Emerson Urizzi Cervi}

L'article intègre les travaux portant sur les relations entre l'arène politique législative et l'arène politique électorale, dénommées « connexion électorale ». L'objectif est d'analyser les interactions entre ces deux arènes dans un système de représentation politique sous-national : le législatif de l'état du Paraná. À partir de cette relation entre la production législative individuelle des députés dans la 14ème législature de l'Asemblée Législative de l'État du Paraná (ALEP) et la performance électorale de ceux qui disputent la réélection, on cherche à identifier des éventuels résultats électoraux des candidats à la réélection. À cet effet, outre les résultats électoraux des candidats à la réélection, qui ont donné naissance à une typologie du vote (aussi bien concentrée ou non concentrée au niveau de la région) comme variable dépendante, trois ensembles de variables explicatives sont compris dans le modèle. Le premier est formé des variables sur la position politique institutionalisée (groupe auquel on appartient ; idéologie ; parti politique ; exercice de fonction auprès de la présidence de l'assemblée ; nombre de mandats à l'ALEP ; et position à l'égard de thème polémique). Le second porte sur la visibilité du mandat (nombre d'apparitions des parlementaires dans le principal journal quotidien de l'État et genre d'apparition). Le troisième groupe de variables explicatives concerne la production législative individuelle (type de projet de loi proposé ; portée géographique du projet de loi ; portée sociale du projet de loi ; nombre de projets proposés ; et nombre de projets adoptés pendant le mandat). À partir de l'intersection des variables composant le modèle en tests d'indépendance de moyennes et de regressions, le modèle analytique montre que l'existence d'un grand rapport entre les votes concentrés dans la région et une plus grande probabilité de réélection. Les variables explicatives sur la position politique et la visibilité du mandat se sont avérées faibles en ce qui concerne l'explication pour le type de vote, alors que certaines variables sur la production législative individuelle ont présenté un taux élevé de rapport avec le vote régional et, par conséquent, avec une plus grande possibilité de réélection du parlementaire.

MOTS-CLÉS : connexion électorale ; députés de l’état ; production législative ; état du Paraná. 


\section{ARTIGO DA MABEL GRIMBERG}

\section{BEYOND CITIZENSHIP IN ITS “PARTICULARLY BRAZILIAN” FORM: CRITICAL CONSIDERATIONS ON NATIONAL SOCIOLOGICAL PRODUCTION}

\section{Sérgio B. F. Tavolaro}

Brazilian literature on the "adventure of citizenship in Brazil" frequently suggests that the terms of the modern normative order were set up here in a peculiar form, if we consider them in relation to those prevailing in what are referred to as the modern societies of "the center". As an indication of this "exceptional nature", allusions are made to the supposed particularities of the institutionalization of political, social and civil guarantees and obligations in Brazil: the routes taken, the historical sequence that has ensued, the actual depth and breadth of every one of them and of the bases that sustain them, are seen as proof of "Brazilian normative deviance". The present article represents an effort toward critical review. I begin with a specific and selective consideration on recent literature on "citizenship in Brazil" meant to indicate some of the difficulties and analytical dilemmas. This is followed by a problematization of what I consider to be two of the main theoretical anchors of Brazilian social thought, in order to shed light on elements having a decisive influence on interpretations made regarding modern Brazil's alleged "normatively exceptional” character. Finally, I argue for the need for an analytical emphasis on the contingent dimension of citizenship building, in order to avoid "essentializing" approaches to the processes that define our normative order. For these purposes, I will make some historiographic incursions meant to illustrate the type of attempts that have been made to deal with such dilemmas through the operationalization of two key ideas: on the one hand, the notion of political opportunities and on the other, the idea according to which rights and duties are not only juridical categories but also situated practices. .

KEYWORDS: citizenship in Brazil; Political Sociology; modernity; essentialism.

\section{AUTHORITARIAN PENAL JUSTICE AND THE CONSOLIDATION OF A PUNITIVE STATE} IN BRAZIL

\section{Débora Pastana}

The Brazilian democratic transition, still underway today, has run up against enormous difficulty in incorporating penal action. Or, put in yet stronger terms, we could say that the boundaries of democratization processes, delineated through the action of that sector of the State, reveal the possibility that the juridical field remains immune to democratizing change. Although prevailing discourse among law professionals asserts that Penal Justice is undergoing democratization, what we have observed in practice is a strong resistance within the juridical field to assuming political responsibilities within the consolidation of democracy. This article reports analyses and conclusions formulated through observation of the Brazilian penal justice system that gave origin to the thesis entitled "Penal Justice in Brazil today: democratic discourse, authoritarian practice". The research sought to reflect on contemporary criminal justice policy, which has been guided by the widening of repression and the continued use of incarceration. Such policy, carried out in Brazil since the beginning of the 1985 "political opening" has adjusted itself to the liberal project that is also currently underway in the country, as well as in almost the entire Western capitalist world. As we can observe, Penal Justice, even during the execution of sentences, operates in authoritarian and exclusive ways, suppressing the rights guaranteed by law to those who have been sentenced and adopting extremely repressive forms as demonstrated by the extremely sparse benefits that it concedes. Thus, in Brazil, criminality has generally been responded through severe sentences, reflected in the absence of guarantees of 
constitutional rights and ample recourse to incarceration. In this vein, our contemporary democratic governments have frequently adopted a punitive stance that seeks to reaffirm the State's aptitudes for punishing and controlling criminality.

KEYWORDS: penal control; incarceration; democratic tutelage; punitive State; Sociology of Violence.

\section{POLITICAL JOURNALISM AND REPUBLICAN THOUGHT IN LATE $19^{\mathrm{TH}}$ CENTURY} PARANÁ

\section{Amélia Siegel Corrêa}

The crisis of the Brazilian monarchical regime was accompanied by the emergence and expansion of the republican movement at the end of the 19th century. During that period, the press not only became the stage of institutional debates but also had the role of an informal power, linked to the government and political party organization. It was a press that expressed opinions and created a space for partisan commentary. Newspaper columns were used to anonymously air that which could not be expressed publicly in the Legislative Assembly, the Senate or the House of Representatives, thus constituting an alternative tribune for debate. This article seeks to give voice to the different republican models that circulated within these state of Paraná newspapers, relating them to the configurations they were a part of and with the position that they held within local and national fields of power. Furthermore, it is important to recognize that the dominant republican ideas were not disseminated without resistance: rather, they were heard and combated at the local level, although efforts in this regard remained lacking in political force. Our analysis incorporates the Bourdieusian perspective according to which discourses are not only signs to be understood and decoded but also status indicators - seeking to be validated and evaluated - and forms of authority, seeking to be believed and obeyed; in both cases, object of struggles over symbolic power. Analysis of republican discourse shows that Paraná state politics of the late 19th century was more a result of alliances and tensions between groups than the fruit of clear ideological stands. Discourses served mostly as rhetorical weapons which were used to orient intra-elite conflict, moved by the desire for participation. This gave them a generic character, based on a notion of putting an end to privilege without widening citizenship rights..

Keywords: Republicanism; Paraná state; political journalism; federalism; political field.

\section{LEGISLATIVE PRODUCTION AND ELECTORAL CONNECTION IN THE PARANÁ STATE LEGISLATIVE ASSEMBLY}

\section{Emerson Urizzi Cervi}

This article belongs to a field of work that deals with the relationships between the legislative political arena and electoral politics, relations that have been referred to as "electoral connection". Our goal is to analyze the interaction between these two arenas within a system of sub-national political representation: the Paraná state legislature. Through looking at the relationship between the individual legislative action of state representatives within the 14th legislative period of the Paraná State Legislative Assembly (Assembléia Legislativa do Paraná (ALEP)) and the legislative performance of those who ran for re-election we seek to identify possible interdependence between individual parliamentary activity and re-election. For these purposes, in addition to putting together a voting typology on electoral results for candidates seeking re-election (looking at whether voting is regionally concentrated or not as dependent variable), our model also includes three sets of explanatory variables. The first is made up of variables regarding institutionalized political position (parliamentary group affiliation, ideology, political party, position occupied within the legislature, number of ALEP mandates served and position on polemic issues). The second looks at the visibility of the mandate (number of 